УДК 78(092)

\title{
Unknown Pages of Alexander Kenel`s Biography
}

\author{
Valentina P. Barabash* \\ Krasnoyarsk Regional College of Culture and Art \\ 3 Krasnykh Partisan Str., Minusinsk \\ Krasnoyarsk region, 662608, Russia
}

Received 12.06.2014, received in revised form 10.09.2014, accepted 11.10.2014

The article highlights the basis of previously untapped historical sources separate biography pages of the first professional composer of Khakassia, public figure, educator, folklorist Alexander A. Kenel. The author first presents the documents, which provide a more complete, new vision of the composer's family history, his training in various educational institutions of the Northern capital, identifies causal relationships of his actions and deeds. The article examines the steps of $A$. A. Kenel in obtaining vocational education, reveals the problem of choice in the new socio-historical situation.

Keywords: A. Kenel, composer, biography, education, choice of the way, Imperial College of Law, the Corps of Pages.

Research area: History.

Alexander A. Kenel being the first professional composer of Khakassia, folklorist, teacher, educator and public figure lived in Siberia for over 30 years: Novosibirsk, Krasnoyarsk, Abakan. Several articles in encyclopedias and anthologies were written about this versatile person (Giguashvili, 1997: 6. Art, 1961: 44. Musical, 1990: 246. Musical, 1997: 440. Klauze 2010: 37. Stoyanov, 1975: 80. Encyclopedia, 2007: 272). But those printed publications are still full of inaccuracies and references to untested or incomplete sources. There are «white spots» in his biography, that distort the historical image of the well-known musician and therefore lead to biased estimates of his activities, form a certain mythology.

The purpose of this article is an attempt to present new research, new light on certain aspects of the life of A.A. Kenel, giving an explanation of his deeds and actions.

Alexander A. Kenel was born in 1898 in St. Petersburg in anoble family. His great-grandfather, Alexander K. Kenel, son of Napoleon's soldier, who stayed after the war of 1812 in Russia, taught French in commercial school in St. Petersburg ${ }^{1}$. His grandfather, Vasily A. Kenel, a graduate of Russian Academy of Arts, was a famous architect, a personal architect Grand Duke Vladimir, held the rank of state councilor ${ }^{2}$. Alexander's father, Alexander V., after graduating from the Imperial College of Law in 1892, served as an architect in the same college, was also well-known architect in the city and held important positions in the city administration ${ }^{3}$.

Having moved to Siberia in 1930-s and filling in various required by administrations of

(C) Siberian Federal University. All rights reserved

* Corresponding author E-mail address: vpb2005@yandex.ru 
the institutions documents: sheets of accounting personnel, autobiographies, questionnaires, checklists, declarations, Alexander never mentioned about the origin, activities of their relatives and parents. He wrote about his mother that she was "of middle-class family,» about his father he wrote that he was «an employee, a civil engineer and architect $\rangle^{4}$.

Alexander was the only child in the family and was surrounded by care, attention and desire of parents to give their son a good education and a bright future. Up to 8 years Alexander received education at home, studied piano, read books, listened to music. Chronology of education process of A.A. Kenel looks the following way:

- 1906 - 1914 - School of the GermanFrench Evangelical Reformed Church (the Reformatory School);

- 1914 (Sept.) - 1917 (Feb.) - Imperial College of Law;

- 1917 (Feb. - Sept.) - the Corps of Pages of His Imperial Majesty;

- 1917 (Sept. - Dec.) - service in the imperial army;

- 1915 - 1916, 1918. - Studies in music courses of I. A. Glasser;

- 1918 - he entered the third course of the Economics Faculty in Polytechnic Institute, worked; somehow he transferred subjects and marks he got in Imperial College of Law, and received a certificate of completion of the University of Petrograd;

- 1919 (June) - 1920 (Sept.) - service in the Red Army;

- Sept. 28, 1920 - the first attempt of entering the Petrograd Conservatoire on specialty «Theory of composition». Studied less than a year.

- 1921 - 1923 - studies on the department of Rhythm and Plastics of the Institute of Performing Arts (graduated in June, 1923);

- 1923 (Sept.) - 1927 (June) - the department of «Theory of composition», Leningrad State Conservatory;

A.A. Kenel received general education in the Reformatory School, from 1906 to 1914 at the high-school course (period of study -8 years). A Reformatory School was an educational institution at the Reformed Churches for three Reformatory parishes of St. Petersburg, on the Embankment of river Moyka st., 38. It was formed in 1818 by the reformatory congregation of St. Petersburg - based on pension of pastor J. von Muralt. This school was for all social classes, it had three courses: gymnasium (8 years), real (7 years) and commercial (certificate was not issued). Upon entering to the College of Law the gymnasium education of A. A. Kenel was noted. In the Reformatory School they taught history, law, Latin, Greek, German and French, a number of general subjects, as well as commercial and political geography of mathematics. The level of teaching was high. Graduates had the right to join the military and the civil service and enter universities. In Reformatory School Alexander had studied German and French very well, knew Latin, but he didn't succeed in the knowledge of Greek, even had 2 points 5 . Documents explaining why the boy of the Orthodox faith was sent to the school where studied mainly Lutherans and other representatives of the Protestant brunch, we were not found.

Further step in the education of A. A. Kenel seems to us problematic in terms of its scrutiny and inaccuracies in the sources and publications. Articles about A.A. Kenel say that in 1915 he entered Petrograd University, Law faculty (Giguashvili, 1997: 6. Klauze, 2010: 37). The same fact Kenel himself notes in his unfinished biography essays and in all personal files which we managed to study. But is it true 
to fact? We have made a number of requests in the archives of St. Petersburg and the current archives of the St. Petersburg University, State Conservatory.

Found documentary sources allow us to propose a different version of A. Kenel's education. Central State Historical Archives, St. Petersburg (TSGIA SPb) store attestation notebook of a pupil of Imperial College of Law Alexander Kenel, a son of State Councilor Alexander V. Kenel, who was accepted to study in class IV as externalities in September 1914, order № 88. In this notebook there are proofs of his belonging to Orthodox religion. Form master K. Hahn gave the following characteristic of A. Kenel: "entered by the exam from the Reformatory School. Almost a little boy, quiet and modest, well-bred"6. In 1915 he was transferred to III class (month is not specified). On the transferring conference he received full score - 12 points. In April, 1916 he was transferred to II class according to the 1st category with 12 points. In December, 1916 A. Kenel took the exam to go to I class (points are not mentioned) and in January 1917 he was transferred to I class according to the 2 nd category ${ }^{1}$. From I class Alexander passed the "ecclesiastical law" - 12 points, civil law - 10 points, civil proceeding 12 points"7.

Marks in examinations confirm the high success A.A. Kenel while studying at Imperial College of Law. Alexander Kenel graduated from this college in February, 1917. It was accelerated 79th issue, which combined several senior classes. (Annenkova, 2006: 357. Pashenny, 1967: 242) Certifying notebook indicated that in February, 1917, immediately after graduation, Alexander entered the Corps of Pages of His Imperial Majesty ${ }^{8}$. We have further information about what A.A. Kenel after accelerated graduation from this Corps he was promoted to ensign and adopted at a general meeting of officers in the company of the officers of the Life Guards of Preobrazhensky
Regiment. A. Kenel was assigned to serve in the third separate heavy artillery battalion lit. "A"

Thus, we have confirmation that A.A. Kenel after Reformatory School from 1914 to 1917 in accelerated manner graduated from Imperial College of Law and His Imperial Majesty's Corps of Pages.

Acceleration was determined by started in 1917 well-known to us revolutionary events of 1917 - 1922. They included the demise of Nicholay II, February and October events. And all this was going on in the background and in circumstances of the First World War of 19141918. Alexander was not only witness to them, but also a participant.

The events of 1920-1930-s associated with the revolutionary reforms, civil war, the new government persecution of everything that resembled a royal past, forced Alexander Kenel be silent about many of the events of his past.

Nowhere and never A.A. Kenel mentioned his study in the elite for Tsarist Russia educational institutions. Only in the personal file at the Leningrad Conservatory, he notes that in September 1917 he was sent to the headquarters of a separate artillery battalion in the village Detskoye and in the personal file of Abakan music school scantily indicates his service in "the old army in September - December 1919"10.

We can assume that in 1918 Alexander turned to the Petrograd University requesting to transfer subjects and marks he got in Imperial College of Law and to give him a diploma of the Law faculty of the University. Anyway, the archives of St. Petersburg University, St. Petersburg CSA, where we have made a request, the information about A.A. Kenel for the period of 1917 - 1919 was not found. ${ }^{11}$

The only indirect evidence that the document about graduation was issued is the archival reference of the State Archive of the October revolution and socialist construction in 
the Leningrad region of 14 March, 1947 № 1128, is available in a personal file of A.A. Kenel in the fund of Lermontov Khakassky Drama Theatre. Apparently, the information was given to the request of the theater management and it states that "in a personal file of the student of the Leningrad Polytechnic Institute A.A. Kenel 1898 birth there is a private application for return of a certificate of completion of the Petrograd University. The application has a label "Certificate gained back 29 October, 1918. Kenel." The certificate listed the original data - AOR -3, F. 3121, op. 225, d. 4, p. $1971^{12}$.

This archival reference was even notarized in Abakan. Apparently, it was the only document confirming his university studies. Thus, we can assume that A.A. Kenel, later got into difficult life situations, tried to conceal the origin of the noble father and their (his and his father) prestigious education in pre-revolutionary Russia. Perhaps he studied at the University of Petrograd for some period of time in order to transfer subjects and marks he got in Imperial College of Law. Time was a revolutionary, military, troubling and it is difficult to imagine how he found a way out of this situation.

Our conclusions support E.A. Annenkova and N.L. Pashenny, who note that the former legists and lyceum students of liquidated after 1917 elite educational institutions were persecuted by the new regime, subjected to repressions. It became dangerous to come together to celebrate the foundation day of the college. In 1920 as a result of the investigation on the "case lyceum students and legists", accused of spying for Britain and Germany, many were shot, sent to prisons and exiles (Annenkova, 2006: 173. Pashenny, 1967: 200). Therefore, it was dangerous for the graduates to confess in noble origins, in graduating from the elite noble educational institution.

In addition to the University of Petrograd A.A. Kenel mentions in the documents when completing his personal files, getting a job in the Khakassky Drama Theatre, music school the Faculty of Economics of Polytechnic Institute. $\mathrm{He}$ notes that he graduated in an accelerated manner finishing the four courses without having to defend the diploma. Subjects studied at university (or Law College?) were transferred and he immediately was taken the third course. There is also a mention of the fact that he was sent in 1920 from the army to complete his education in Polytechnic Institute ${ }^{13}$. Namely from the Polytechnic Institute a certificate was presented that he is a student of Economic department of the IV course on entering the conservatory. It is strange that in the list of documents in the conservatory there is no certificate of completion of the University of Petrograd, which we mentioned ${ }^{14}$.

So, after the Imperial College of Law A. Kenel studied in the Corps of Pages, and in this time his family great sorrow came to his family - his father died from an insult. Alexander had to think about earning, to support himself and his mother. Alexander gets a job of a clerk financial and legal department of the Agricultural Committee on Petrograd communal services, and from January, 1919 he was already working as a press-corrector of a magazine "New Way", in the printing office №14 ${ }^{15}$.

In June, 1919 A. Kenel was conscripted into the Red Army. This was not the first experience of service. From September to December 1917, in the midst of the revolutionary events Alexander was in the Tsarist army, in the village Detskoye, as a graduate and Officer of the Corps of Pages, as was noted above. At this time in the army were tumultuous events associated with the beginning of the revolution. Alexander was even elected to the military tribunal of the unit ${ }^{16}$. In the second conscription he had served in the Red Army already, in the fortress of Kronshtadt on sea forts. Militarily ticket stated that he was an 
soldier, skilled heavy machine gunner, attached to the air defense headquarters as an assistant of a platoon commander of heavy machine gunners from October, 1919 to November, $1920^{17}$. As he writes in his autobiography, he had to fight with the Yudenitch troops at fort Krasnaya Gorka, at the forefront, there was even a slight concussion. After the defeat of the Yudenitch troops he worked in Kronshtadt on liquidation of illiteracy in the Red Army, schools, circles, was engaged in cultural-educational work. He was transferred to the reserve in November, 1920.

Meanwhile, the application for studying in Petrograd Conservatory was filed in September 28, 1920. He managed to escape from Kronshtadt, as he pointed out, to complete his education at the Polytechnic Institute, but he entered the conservatory $^{18}$. Thus, Alexander, in 1920 tried to study at two universities simultaneously. At the same time he worked as he had to maintain his family. As a result, in 1921 he leaves the conservatory, works and decides again to enter the educational institution connected with arts.

In 1921 he entered the Institute of Performing Arts at the Faculty of Rhythm and Plastics. He had a desire to take up conducting in the future, where rhythm and plastics were needed. Confirmation of education at the institute (1921-1923) is the placement №726 of the Administration of the Institute of Performing Arts dated by August 14, 1923 to the Union of Artists. Management of the Institute asks the Union of Artists "to send to the State Conservatory, Theory Department, Alexander A. Kenel, graduated from the Department of rhythm, who showed great musical talent, but still need to keep the musical theoretical training"19. Thus, A.A. Kenel entered the conservatory for the second time in 1923. This is confirmed by the data profiles and declarations that he filled in the conservatory - "accepted to the university in 1923 by the placement of the Union of Artists" 20 .
On what means did Alexander Kenel live in the early 1920s? He indicates in the questionnaire of the conservatory: "Accompany, write music to orders, a member of a living newspaper group "Blue Blouse", which hold concerts in the workers' clubs, where I earn $20-40$ rubles. Read lectures on the theory and history of art, write music for the verse, make arrangements..." In another questionnaire he noted that earnings per month range from 20 to 60 rubles. The certificate, issued to A.A. Kenel in November 17, 1925, confirms that "he is an artist (pianist) in the work collective of "Blue Blouse", organized by the Leningrad labor exchange of unemployed from to Union of Artists, and from August 1 to September 1, 1925 he received a salary at the rate of 15 category, which was reflected in the amount of 40 rubles 63 kopecks." 21

Thus, being the only worker in the family, living in raging in the civil war and revolutionary changes society Alexander Kenel was forced to make important decisions in his life, to work, to learn how to survive in these conditions. In an unfinished manuscript "Essays of biography", he wrote that fulfilled his dream to study music professionally, against his father's will. Father, being proud of ancestors' biography, of his own famous father-architect, dreamed of continuing glorious career by his son. Hence the communion of Alexander to study at the elite gentry Law College (continuation of what he studied himself), military service (Corps of Pages) as an indispensable duty of nobleman, continuation of military career of his distant French ancestor.

While the father was alive, Alexander served his suggestions and advice. But after his father's death he had a choice. Judging by the fact that he entered the Faculty of Economics, then tried to study at Archaeological Institute (even passed several exams), he had doubts about the choice of a profession, the uncertainty, the desire to have many occupations. 
He decided to devote his life to music, to get a profession connected associated with it, to serve as a musician under the influence of his mother, Natalya. Since childhood, she taught him playing the piano, she was musically gifted, sang a lot, played and her son loved music thanks to her. He joined the music by visiting famous music courses of I.A. Gliasser, where he met young, talented Dmitry Shostakovich, companionship with which he preserved for a lifetime ${ }^{22}$.

So, after all doubts, finding the best profession, the right way, in 1923 Alexander Kenel entered the Leningrad Conservatory Composition Department and in 1927 graduated from it. Thus, "fulfilled his pursuit of art, against which at one time was his father"23.

Another mystery, which he hid in his life, is his staying in Gulag in 1927-1929 for participation in the Masonic organization " Holy Grail" (Klauze, 2010: 38).

As it was noted by I. Klauze, "the fate of A.A. Kenel is far from unique... The beginning was promising...” ( Klauze, 2010: 37). But A.A. Kenel ended his way in Siberia, passing through many trials.

Alexander Kenel was widely educated man. Summing up the results of our investigations, we can definitely name those institutions in which he studied and graduated from. Unfortunately, we couldn't find any diplomas of higher educational institutions not in archives or in personal files and archives of educational institutions or places of his work. Kenel himself writes about it, that "... a lot documents stored at my mother were lost during the blockade of Leningrad, for example, higher educational diplomas..."24.
But even judging by indirect document sources we can already have more or less complete picture of how and where Kenel got professional knowledge and skills.

If today he had a chance to write his autobiography, he would openly write that he received a classical gymnasium, legal, military, economic, musical education. He knew several foreign and ancient languages, in Khakassia he studied the Khakassian language.

Certainly, the emergence in Siberia and in Khakassia of a musician and a person with such a brilliant education was to give and gave impetus to the development of culture and art.

KHNKM - Khakassky Nacional'ny Kraevedchesky Muzey im. L.R. Kyzylasova [L.R. Kyzylasov Khakass National Regional Museum]

NA RKH - Nacional'ny Arkhiv Respubliki Khakassiya [the National Archives of the Republic of Khakassia]

RGVIA SPb - Rossiysky Gosudarstvenny Voenno-Istorichesky Muzey po Sankt-Peterburgu [Russian State Military-Historical Museum, St. Petersburg]

RF KhakNIIYALI - Rukopisny Fond Khakassogo Nauchno-Issledovatel'skogo Instituta Yazyka, Literatury i Istorii [Manuscript Fund of the Khakass Scientific-Research Institute of Language, Literature and History].

TSGALI SPb - Tsentral'ny Gosudarstvenny Arkhiv Literatury i Iskusstva po Sankt-Peterburgu [Central State Archives of Literature and Art, St. Petersburg]

TSGIA SPb - Tsentral'ny Gosudarstvenny Istorichesky Arkhiv po Sankt-Peterburgu [Central State Historical Archives, St. Petersburg]

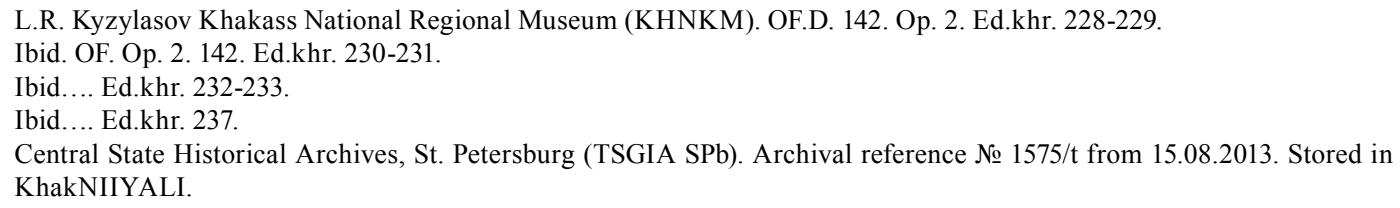


Central State Historical Archives, St. Petersburg (TSGIA SPb). F. 335. Op. 1. D. 1401, L. 1ob.

Ibid.... L. 3ob.

Ibid... L. 4.

9 Russian State Military-Historical Museum, St. Petersburg (RGVIA SPb). Archival reference № 3754 from 19.12.2013. Stored in KhakNIIYALI.

10 Current Archives of A.A. Kenel Abakan Musical School. Personal file of A.A. Kenel. L. 2.

11 Central State Archives, St.Petersburg (TSGA SPb). Archival reference № 376/t from.30.03.2012.

12 National Archives of the Republic of Khakassia (NA RKH). F. 461, Op.1. D. 25, L.38.

13 Manuscript Fund of the Khakass Scientific-Research Institute of Language, Literature and History (RF KhakNIIYALI), personal file of A.A. Kenel, 1.2 .

14 Central State Archives of Literature and Art, St. Petersburg (TSGALI SPb). F. 298, Op.2, D. 1459, L.1.

15 Manuscript Fund of the Khakass Scientific-Research Institute of Language, Literature and History (RF KhakNIIYALI), personal file of A.A. Kenel, 1.2.

16 L.R. Kyzylasov Khakass National Regional Museum (KHNKM), A.A. Kenel Fund. D. 142, Op.1, Ed.khr. 237.

17 National Archives of the Republic of Khakassia (NA RKH). F. 606, Op.1. D. 63, L.72.

18 Central State Archives of Literature and Art, St. Petersburg (TSGALI SPb). F. 298, Op.2, D. 1459, L.1.

19 Central State Archives of Literature and Art, St. Petersburg (TSGALI SPb). F. 298, Op.2, D. 1459, L.1.

20 Ibid. ... L. 3 .

21 Ibid. ... L. 5.

22 In the National Archives of the Republic of Khakassia (NA RKH), in A.A. Kenel’s Fund (№ 606) are stored documents which prove these relationships.

23 National Archives of the Republic of Khakassia (NA RKH). F. 461, Op.1. D. 25, L.34.

24 National Archives of the Republic of Khakassia (NA RKH). F. 461, Op.1. D. 25, L.35.

\section{References}

1. Annenkova, E.A. The Imperial College of Law. St. Petersburg, 2006.

2. Encyclopedia of the Republic of Khakassia. Abakan, 2007.

3. Encyclopedic Dictionary of Music. Moscow, 1990.

4. Giguashvili, T.S. Music - is their life. Abakan, 1997.

5. Klauze, I. Destiny and art of A.A. Kenel, collaborator of G.M. Rimsky-Korsakov in a circle of “Quarter-tone music”. St. Petersburg, 2010.

6. Musical culture of Siberia. Vol..3 b.3. Novosibirsk, 1997.

7. Pashenny, N.L. Madrid, 1967.

8. Stoyanov, A. Alexander Alexandrovich Kenel. Light your star. Abakan, 1975. 


\section{Неизвестные страницы биографии}

\section{Александра Кенеля}

\section{В.П. Барабаш}

Красноярский краевой колледж культуры и искусства Россия, 662608, Красноярский край, Минусинск, ул. Красных партизан, 3

В статье освещаются на основе ранее неиспользованных исторических источников отдельные странииы биографии первого профессионального композитора Хакасии, общественного деятеля, педагога, фольклориста Александра А. Кенеля. Автор впервые представляет документы, которые обеспечивают более полное видение семейной истории композитора, его обучение в различных учебных заведениях Северной столицы, определяет причинно-следственные связи в своих действиях и поступках. В статье рассматриваются этапы А.А. Кенеля в получении профессионально-технического образования, раскрывается проблема выбора в новой социально- исторической ситуации.

Ключевые слова: А. Кенель, композитор, биография, образование, выбор пути, Императорское училище правоведения, Пажеский корпус.

Научная специальность: 07.00.00 - исторические науки. 